\title{
The peer composition of pre-school settings in England, and early recorded attainment among low-income children
}

Kitty Stewart*, Tammy Campbell, Ludovica Gambaro*^

${ }^{*}$ Centre for Analysis of Social Exclusion, London School of Economics

Houghton St, London WC2A 2AE

${ }^{\wedge}$ DIW Berlin

Mohrenstraße 58, 10117 Berlin, Germany

t.campbell1@lse.ac.uk

I.gambaro@ucl.ac.uk

K.J.Stewart@Ise.ac.uk

\section{Acknowledgements and Funding}

We would like to thank the Nuffield Foundation for funding this research. The Nuffield Foundation is an endowed charitable trust that aims to improve social well-being in the widest sense. It funds research and innovation in education and social policy and also works to build capacity in education, science and social science research. The Nuffield Foundation has funded this project, but the views expressed are those of the authors and not necessarily those of the Foundation. More information is available at www.nuffieldfoundation.org. Many thanks also to the Department for Education for use of the National Pupil Database (NPD), and to the NPD Requests Team, for facilitating access. Lastly, we would like to thank colleagues in the Centre for Analysis of Social Exclusion, our project advisory group, and two anonymous reviewers, for helpful comments and suggestions. 


\section{Abstract}

Evidence suggests that early education can promote children's development, and narrow attainment gaps between those from lower- and higher- income families. However, realisation of these potential benefits depends on many factors, feasibly including peer composition.

We use national census data for a year-group cohort of children in England in 2011, to answer two questions. How are low-income children distributed across preschools? And what is the relationship between the proportions of low-income peers in a low-income child's setting, and these children's subsequent recorded educational attainment?

In contrast to many European countries and to the US, we find the majority of lowincome children attend mixed settings. We find little evidence for associations between proportion low-income peers and low-income children's early subsequent attainment. We suggest that this may be due to an arguably optimal distribution across settings, where the funding and provision context of 2011 facilitated a lack of clustering of low-income children.

\section{Introduction}

In recent years, early education and care has been afforded increasing priority and spending across many countries. Evidence suggests it can promote children's development (Dumas and Lefranc, 2012; Ruhm and Waldfogel, 2011; Duncan and Magnuson, 2013), and narrow attainment gaps between those from lower- and higher-income families (Burger, 2010). However, attending early education does not 
inevitably, of itself, lead to heightened trajectories: the nature of the experience is important.

There has recently been a growing focus on 'process quality,' and on associated features such as staff qualifications and staff:child ratios (Mathers et al, 2011; Blanden et al, 2017). One aspect of children's experience that has received relatively little attention, however, is peer constitution. Research with school-aged children has, in contrast, examined peer make-up, identifying evidence of relationships with children's educational and behavioural outcomes (Sacerdote, 2011). At pre-school level, less is known about the extent of clustering by family characteristics and about possible impacts - especially in European contexts.

Yet setting composition may be instrumental to development, as children in group-based early education spend considerable time interacting with each other. In many European countries, there are factors pushing towards clustering of children along socio-economic lines at this stage - more so than in compulsory schooling, where the range of options open to parents tends to be smaller, and admissions criteria more centralised and transparent.

In this paper, we consider the relationship between peer make-up by incomelevel in early education, and low-income children's subsequent measured attainment. We use large-scale data from an English national census spanning all publicly funded pre-school and school-age children's educational provision and recorded attainment. We choose income poverty as the dimension of interest because, in England, low-income children are disadvantaged throughout education, even accounting for other social and demographic characteristics (Department for Education, 2014; Department for Eduction, 2015; Taylor, 2017; llie et al, 2017). 
Our study therefore differs from recent research on school and class composition, which has focused mainly on immigrant and minority ethnic status (e.g. Biedinger, Becker, and Rohling, 2008; Cebolla-Boado and Garrido Medina, 2011), underpinned by the confluence of immigrant / minority ethnic status and class in various European countries. In England, several minority ethnic groups outperform the majority (White British pupils), and low-income White British children are among the lowest achieving groups at all stages of education (Equality and Human Rights Commission, 2015; Kirby and Cullinane, 2016). In this context, income-level in itself is a key delineator, and it is the aspect of peer composition on which we focus. To what extent are children from low-income households clustered together in early education settings, and does the level of clustering seem to make a difference to their attainment in early primary school?

\section{Evidence on peer composition and children's development within early education}

Children begin to develop social skills and establish peer relationships in the pre-school years. Indeed, promoting social competencies is an explicit objective of most early childhood practice, resulting in an emphasis on peer-to-peer communication. Thus there are likely to be ample opportunities for peers to influence each other directly, and there are several ways in which the proportion of children who are low-income in a setting might potentially influence the progress of attendant children.

One way is through direct effects, as children learn from or mimic one another. Peer group make-up may also indirectly affect interactions between adults and children. Staff might pitch activities and discussion to the perceived abilities or 
interests of a group; in more diverse settings, children may benefit from a wider range of material and opportunities. Conversely, however, homogeneity might enable teachers to design activities or engage children more effectively.

Emerging evidence from the US supports the possibility of associations between children's progress and peers' skills and behaviour. Several studies have examined language development as a key malleable factor during the pre-school year, and indicate that children make more progress when situated with peers with higher language competence (e.g. DeLay et al, 2016; Henry and Rickman, 2007; Justice et al, 2011; Mashburn et al, 2009; Schechter and Bye, 2007).

Research from European countries, where pre-school enrolment tends to be free and widely accessed, is scarce. Ribeiro et al (2017) sought to replicate findings from the US in the Norwegian context but did not detect any peer effects. Using German data, Ebert et al (2013) examined vocabulary development and found a small association with peers' language input for children who did not speak German at home.

If peer skills do make a difference to children's progress, composition according to children's income-level is potentially important, given that differences by family socio-economic status in children's abilities and behaviours occur across countries (although their extent varies, depending on context and outcome) (Bradbury et al 2015; David, 2010; Duncan and Magnuson 2005). In England, children who are eligible for Free School Meals (FSM) in reception class of primary school do significantly less well on average in teacher assessments at the end of that year: $56 \%$ of children in receipt of FSM achieved a 'good level of development', compared to $72 \%$ of other children (DfE, 2017 ; the measure is discussed further below). 
The reasons for this gap are complex; among other factors, the gap may reflect lower average levels of parental education in low-income households, a tendency to less exposure to high quality childcare, and the impact of low income on the home environment - including fewer books, toys and outings, on average, and a higher risk of parental anxiety and depression (Cooper; 2017; Cooper and Stewart, 2013). If children from lower income families tend to enter early education with more limited language skills and having experienced fewer opportunities for cognitive development, clustering by income level could itself be one determinant of the attainment gap, via the direct and indirect peer mechanisms discussed above.

Three US studies move research in the direction of examining peer effects by income-level. Schechter and Bye (2007) examine trajectories during the prekindergarten year, and indicate greater language gains for disadvantaged children in mixed preschools than for those in preschools serving only low-income families. Weiland and Yoshikawa (2014) find children in centres with proportions of lowincome children above the district mean of $32 \%$ seemed to benefit from the presence of children from higher-income families, with improvements in measures of receptive vocabulary and executive function. Miller et al (2017) also indicate, overall, that lowincome children in centres with a lower proportion of peers also from low-income families have higher academic progress, though they find evidence of non-linearities. For language development, negative associations were suggested only when the proportion of low-income children was between $25 \%$ and $45 \%$. For maths, negative relationships were observed only in settings with $52 \%-72 \%$ children from lowincome families. This indicates that changes in the make-up of a setting are likely to have differential effects depending on whether or not they straddle such tipping points. These non-linearities also highlight potential complexities of associations 
between peer-compositions and the development of children within a group. There is not a straightforward 'dosage' effect of exposure to similar / dissimilar peers, for example; dynamic social and cognitive processes are engendered by different peer mixes.

In England, peer socio-economic mix has been related to the development of low-income pre-schoolers in an observational sample, but non-linearities were not investigated (Sylva et al, 2004). For older children, more comprehensive analyses of English census data do suggest non-linear patterns, though these are different to those in the US research with pre-schoolers. Among school pupils, there is a link between peer constitution and attainment that is U-shaped or 'ski-jump.' Up to a certain point, having a higher share of peers similarly low-income appears negatively associated with attainment for low-income pupils, but a higher proportion of similar peers (approximately 35\%+) appears to reverse this trend, and is positively related to attainment (Shaw et al, 2017; Sutton Trust, 2009). This suggests that a certain density of children who are potentially more similar may comprise a critical mass which might, for example, enable support and opportunities to be pitched appropriately to facilitate progress, or which may enable positive social and cognitive processes to take place.

\section{Institutional context: forces for separation and mixing in early education in}

\section{England}

England's context is an interesting one in which to study pre-school peer constitution by income-level, not least because of the assortment of factors that may influence patterns of mixing.. Some factors have the potential to promote 
consistency, universality and uniformity, feasibly discouraging sorting, while others produce difference, and may lend themselves to selection and clustering by parents.

Since 2004, there has been a universal entitlement to a free, part-time, early education place for all children in England, from the term after their third birthday. 15 hours per week were available in 2011, the focal year in this paper. Almost all three and four-year-olds (estimated between 90-98\%; Gambaro et al, 2015) take up at least one year of early education immediately preceding their formal schooling, which begins in the September after they turn four.

A statutory curriculum, the Early Years Foundation Stage (EYFS), has been in place nationally since 2003 (Bradbury, 2014). It 'sets the standards all early years providers must meet' and 'seeks to provide...quality and consistency.' It prescribes 'activities and experiences' with which early education centres must comply, and is linked directly to 'early learning goals,' which are assessed once pupils have completed their first year of primary schooling, at age five (Department for Education, 2014). The EYFS therefore seeks to promote some level of uniformity in English early education.

In addition, all centres that receive any public funding are inspected regularly by the Office for Standards in Education, Children's Services and Skills (Ofsted), which assesses providers against a charter of requirements, rating them as 'outstanding,' 'good,' 'satisfactory,' or 'inadequate' (Ofsted, 2011). In theory, at least, this maintains a minimum standard - and alongside the homogeneity promoted by the EYFS curriculum, potentially mitigates against selection by parents according to perceived centre quality. Conversely, however, as Ofsted's ratings and reports are publicly available, they inform parental choice, and may have the effect of increasing selection by family background (Burgess et al, 2004). 
Another factor that may encourage sorting is wide variation in centre types. Though the entitlement to attendance from age three is universal, it is delivered by a plethora of providers - state, private and voluntary - in a 'childcare market' (Lloyd and Penn, 2012; Lewis and West, 2017). The options available differ by area. State nursery classes and nursery schools were established by local authorities in disadvantaged urban areas in the 1960s and 1970s (Owen and Moss, 1989), while in other areas, part-time playgroups and pre-schools run by parents and the voluntary sector developed to fill the gap, and consequentially, there is regional variation.

Whether parents are in paid employment also influences the type of early education children attend. Since 1997, there has been a rapid expansion of full-day provision in the private and voluntary sectors, to meet the demands of rising female labour market participation, and encouraged by government (Stewart, 2013). Children can take up their free place in these centres, but often only if their parents pay for additional hours. Many children enter day nurseries as babies or toddlers, with the free entitlement functioning as a reduction in fees at three. Even among working families, however, variation in levels of additional fees charged by full-day nurseries (Huskinson et al, 2016) may provide a further sorting mechanism, and childcare subsidies differing by income-level further complicate this picture (Stewart and Obolenskaya, 2015).

There are also differences in staff qualifications and ratios across early education sectors, which, again, may promote sorting. State nursery schools and classes must have a qualified teacher in the classroom (but can have more children per adult), while private and voluntary providers face less stringent qualification 
requirements (but must correspondingly have a higher staff:child ratio) (Gambaro et al, 2015).

So while nearly all three- and four-year-olds in England access free part-time early education, and while there are national regulatory factors that promote consistency, parents can 'chose' between centres that vary considerably, and this (more or less conscious and constrained) 'choice' depends also upon the make-up of provision in their local area. Some aspects of this mixed system may result in less clustering by background in England than in the US, for example, from where most evidence on sorting and peer effects in early education comes. But high levels of clustering may also be expected given a situation where, predominantly, 'middle class and...working class parents [have been] engaged with different "circuits of care"' (Vincent et al, 2008).

\section{The present study}

To date, little is known at the national level about the extent of sorting into early education in England, or about whether any aspect of peer constitution at this stage appears to influence gaps in English children's trajectories. We ask: is clustering by income-level happening at scale in English early education, and does it relate to the attainment of children from lower-income households?

Exploring these questions is important because low-income children in England lag behind their peers throughout education; because there is evidence that intervening early could narrow these gaps; and because existing evidence suggests that peer constitution may be one relevant (and under-researched) factor influencing early development. The focus on pre-primary education also allows us to extend 
downwards existing research on associations between later school composition and children's attainment.

We therefore address two main questions:

1. How are low-income children in England distributed across early education centres in the year immediately before formal schooling?

2. What is the relationship between the proportions of low-income peers in a low-income child's early education centre, and these children's subsequent educational attainment?

\section{Methods}

\section{Data and sample}

We use records from the National Pupil Database (NPD), a census of all children in England who access state-funded education. The NPD begins following children once they receive funding for education in the pre-school years, and continues to the end of secondary school. Information can be linked longitudinally at the pupil level, and includes detail on each institution attended, on children's recorded personal characteristics, and on their attainment in national tests and assessments.

We examine children born into the 2006-07 academic year cohort who attended early education in January 2011. Their record during the pre-school year is supplemented with information from three subsequent years - reception, year 1 and year 2 - giving us four observational points spanning January 2011 to January 2014. Table 1 describes the key data linked, reporting variables available and year of collection. 
The analytical sample includes 553,327 children nested in 24,727 early education centres. Starting from the whole school year cohort $(\mathrm{N}=617,645)$, we exclude children who: i) were enrolled in centres with fewer than five cohort peers or in home-based provision ( $\mathrm{N}=9,377)$; or ii) had missing information on outcome measures (Foundation Stage Profile and Key Stage One test scores $(\mathrm{N}=54,941))$.

We also link in data on each centre's results from their Ofsted inspection, and area-level measures of child poverty.

\section{Variables}

See Table 2 for descriptive statistics for all variables.

Measure of low income

Because no individual-level measure of income or family economic circumstances is available for the year in which children attend early education, we construct a proxy for low income, using subsequent information on claiming free school meals (FSM).

Until 2014, children in England were entitled to FSM in early primary school only if their family was in receipt of unemployment benefits or on a very low wage (Iniesta-Martinez and Evans, 2014). Thus FSM receipt serves as a proxy for low income, and has been supported as a measure that is reasonably reliable and valid, though simplistic and not fully comprehensive (Taylor, 2017; llie et al, 2017). From 2014, school meals became free universally in the first three years of school, so our cohort is the last for whom a more reliable longitudinal future-FSM variable is available. 
In later education, children who claim FSM for the longest attain the lowest academic scores (Gorard and Siddiqui, 2018), and we assume that families who persistently claim FSM throughout the first three years of their child's formal schooling are highly likely to have had low incomes in the year immediately preceding this, when the child attended early education. This is supported by analyses of detailed cohort study data for an English sample across proximal years, which identifies a sub-group of families whose low income persists through their child's pre-school period and into their schooling (Dickerson and Popli, 2012).

Thus we denote as low-income in 2011 children recorded as claiming FSM in each of the years 2012, 2013, and 2014 ('always FSM', 12.4\% of the sample). We also distinguish cases who are 'sometimes FSM' (once or twice in these years, $12.1 \%)$ from those who are 'never FSM' (75.5\%).

While FSM receipt allows us to denote children from low-income families, those classified as 'never FSM' are a heterogeneous group, including children entitled to FSM but not claiming, children just above the threshold, and children from families ranging from middle income to highly affluent. Due to this diversity, we cannot investigate the impact of low-income peers on non-low-income children, because we cannot distinguish the truly higher-income within the non-FSM group.

Measure of proportion low-income peers in early education

We calculate for each individual child the percentage of children who are lowincome ('always FSM') in the centre they attend - excluding the individual themselves from both numerator and dominator. 
Measure of early educational attainment

Our main outcome measures are Foundation Stage Profile (FSP) scores, which are teacher-assessed according to a series of standardised criteria at the end of the first (reception) year of primary school (age five).

The NPD provides no earlier record of children's progress or attainment, so our outcome is a year removed from the experience of peers in early education. While this is a limitation of our analyses - time and subsequent experiences may dilute any short-term effects - it is also a strength insofar as it allows us to ascertain whether there are associations between pre-school peers and attainment as recorded and used in practice in the school context. What is lost in internal validity in measuring the various impacts that peer constitution may have on children's immediate progress is therefore potentially gained in external validity, applicability, and contribution to a wider understanding of factors associated with children's observed longitudinal educational trajectories.

In 2011, reception teachers in England were required to judge every child in their class across the six domains of the FSP: personal, social, and emotional development; communication, language, and literacy; problem solving, reasoning and numeracy; knowledge and understanding of the world; physical development; creative development. Thirteen scales were spread across these areas, and a maximum score of nine could be scored on each (Bradbury, 2014). The sub-scales are highly correlated with one another (see Table 3), so although for completeness we perform sensitivity checks on each sub-scale, we use the summed total score as one of the two main outcomes in our analyses. The range of the FSP total score is 0117 , and in our sample the mean is 89.2 (SD: 15.8). 
There is also a combination of grades across several scales of the FSP which was deemed by the Department for Education to indicate that a child has reached a 'good level of development' (GLD). Children must score a minimum of six across the seven personal, social and emotional, and communication, language and literacy scales, as well as 78 points or more in total. Overall, $64.7 \%$ of our cohort are denoted as having a GLD. This binary outcome provides less nuance than the total score. However, it offers a straightforward measure of a teacher's overall assessment of a child's general development at this stage. Teachers are likely to pay particular attention to decisions that affect whether or not a child is recorded as having a GLD because it is an explicit threshold and target, and may tweak scores on individual scales to reflect their considered judgement and / or external pressures (Bradbury, 2011). Thus while the full score is finer grained, the binary measure may offer a different type of 'accuracy.'

We examine both measures, and also perform analysis using children's later Key Stage One scores. These are teacher assessments, again against standardised criteria, made at the end of the third year of formal schooling, year 2 (age seven).

\section{Covariates}

We control for factors that previous literature suggests are correlated with the proportion of children in an early education centre who are low-income, and/or with individuals' FSP scores (Blanden et al, 2017; Gambaro et al, 2015; Sylva et al, 2004). The child-level variables included are: month of birth; gender; ethnicity; whether the child is recorded as having special educational needs; whether she has English as an additional language; and whether she spends time in early education and care beyond the fully-funded 15 hours (see second panel, Table 2). 
We also include area-based controls, to minimise the possibility that any apparent associations between peer make-up and child outcomes are driven by differences in the local concentration of poverty, or in the structure of early years provision in different parts of the country (see third panel, Table 3). The level of child poverty in a pupil's neighbourhood is measured as the proportion of children living in families on means-tested benefits or below $60 \%$ of median equivalised income. We also control for the government region in which the child lives, and the percentage of early education in the local authority which is state-provided.

Finally, we include available controls for key characteristics of the early education centre attended, (see fourth panel, Table 2). We distinguish between state-maintained provision and other types in the private and voluntary sector. We also delineate centres open all year round and those closed during the school holidays. The presence of graduate staff working directly with children is included, as well as the result of the most recent Ofsted inspection. Lastly, we incorporate the percentage of children in each centre who are from each recorded ethnic group, and the percentage of children who are reported to have English as an additional language. By including these factors, we seek to control so far as the data allows for selection into different centres by parents with different background characteristics.

\section{Analytical strategy}

To answer our first question ('How are low-income children in England distributed across early education centres, in the year immediately before formal schooling?') we present simple descriptive statistics, to illustrate the situation in 2011. However, any description of distribution and concentration patterns requires a benchmark. Research on school and class composition among school-aged children 
usually compares geographical regions (Jenkins et al, 2008; Johnston et al, 2008) or examines trends over time (Allen and Vignoles, 2007; Gorard, 2009). Alternatively, concentrations of pupils in schools are set against residential patterns, to ascertain whether additional sorting operates at school level. In this paper, we take a different approach, and contrast the distribution of children across early education centres to their distribution in early compulsory schooling (year 1 ). This approach allows us to focus on the institutional mechanisms that are distinctive about the pre-school education system, in comparison to the school system, setting aside the effects of residential sorting - which will contribute to both. Institutional mechanisms are arguably more amenable to policy influence than residential patterns.

In addressing our second research question, ('What is the relationship between the proportions of low-income peers in a low-income child's early education centre, and these children's subsequent educational attainment?') our challenge is selection bias. Children are not randomly allocated to particular centres, and peer groups may be correlated with other factors that we cannot observe but that are themselves associated with or relevant for children's development. This will bias results: any detectable 'effect' of peer composition may be the effect of unobservable parent or child characteristics, rather than peers. We cannot completely circumvent this possibility using observational data, but we address it by using both an OLS model with a rich set of controls and, as an alternative, a fixed effects model. Specifically, we use linear regression for each outcome, and control so far as the data allow for potential confounders. We enter these covariates through cumulative specifications: the first model simply estimates the raw association between the proportion of lowincome peers and the outcome; the second controls for child-level characteristics; 
the third adds neighbourhood and area controls; and the fourth adds information about the early education centre.

Finally, a fifth model uses school fixed effects, allowing us to focus on variation in pre-school peer composition among children within the same primary school. Given that the FSP is assessed by the teacher, who to some extent will consciously or unconsciously evaluate each child relative to other children in the year-group, as well as against the specified criteria, a school fixed effects model can capture variation within the cohort that is not a product of selection into or aspects of their school. To the extent that sorting into primary schools is correlated to sorting into early education centres, school fixed effects also reduces the extent of unobserved heterogeneity.

In all models, we interact each child's own income-level (low-income ['always FSM'], 'sometimes FSM,' or 'never FSM') with the level of peers within their centre who are low-income (0\%, 0.1-10\%, 10.1-20\%, 20.1-30\%, 30.1-40\%, 40.1-50\%, $50.1 \%+)$. All children are included in analyses. We classify peer-level categorically to allow for the non-linearities apparent in previous studies, and use reference groups of 'never FSM' and $0 \%$ peers low-income. This produces both main effects for a child's FSM status and her class constitution, and interactive effects. For clarity and parsimony, in the main results we present key model coefficients and estimated marginal means for our focal groups of interest: low-income children attending early education centres with each proportion of fellow low-income peers. These means indicate estimated average scores on the FSP / probabilities of scoring a GLD on the FSP, for each group, controlling for covariates. 


\section{Results}

How are low-income children in England distributed across early education centres in the year immediately before formal schooling?

Figure 1 shows that, overall, most children attend centres where $0-20 \%$ of their peers are low-income ('always FSM'). Very few children ( $0.8 \%)$ attend early education with over $50 \%$ low-income peers. In the main, low-income children are not disproportionately sorted into certain settings. However, there is evidence of milder clustering. Figure 2 presents a kernel density plot showing the proportion of the sample attending centres with each percentage of low-income peers, split by the child's own family's income-level. It shows that children who are themselves lowincome tend more often to have higher proportions of similar peers - but even among this group, only $2.9 \%$ attend centres with over $50 \%$ children from low-income families.

To examine whether children's likelihood of having low-income peers varies by type of centre, we delineate between state-maintained settings (school nurseries and local authority-run nursery schools) and other types of early education. Statemaintained centres are located mainly in inner city areas, where the concentration of poverty is higher, and these centres largely operated a three hour session per day during our focal period, making it difficult for working parents to rely on their provision alone. Both factors are likely to push towards higher numbers of low-income children in the state sector; indeed, $71 \%$ of low-income children in our sample attend state nurseries, compared to $44 \%$ of 'never FSM' children. As a result, children in state-maintained centres are more likely to have higher levels of low-income peers than those in private or voluntary sector institutions, as shown in Figure 3. Even in 
state settings, however, it is rare for low-income children to have a majority of lowincome peers, at just $3.6 \%$ of the sample.

Figures 4 and 5 compare levels of low-income peers for sample children in this early education year (2011) to their experience in their school year-group cohort two years later. Though Figure 4 shows a fall overall in the number of children who have no low-income peers in school compared to in early education, the means and distributions for each income group are very similar across the two time points (Figure 5). There is a reduction in the number of children with no low-income peers, and a corresponding increase in those with $0-10 \%$, along with a very small increase in those with $10-20 \%$. This indicates that some children attend private day nurseries or pre-schools catering only for children with working or higher-income parents. Many of these children appear to move to state primary schools where the intake is a little more mixed. However, there is negligible difference in higher concentrations of lower-income children between the two stages.

So it is more common to attend a nursery with no low-income children than a similarly constituted primary. But children are no more likely to attend an early education centre with more than $20 \%$ low-income peers than they are to attend such a primary school.

Thus the main answer to question 1 is twofold. Children are distributed somewhat unevenly between early education centres according to their incomelevel: across provider-types, and in most areas, low-income children are more likely than higher-income children to have higher numbers of similarly low-income peers. However, extreme clustering is rare, and this is also the case for sample children two years later, in compulsory schooling. Due perhaps to the universal and standardised 
aspects of early education in England, there seems to be a high level of mixing, at least according to family income-level as proxied by recorded FSM.

In addressing question 2, variation relies upon this overall distribution: we compare, in the main, children who have no similarly low-income peers to those with levels of low-income peers ranging from the low to the moderate. The similarity of patterns of sorting at the two stages - early education and primary school - provides support for our use of school fixed effects to limit the potential effect of sorting on unobservables resulting from parental choice.

\section{What is the relationship between the proportions of low-income peers in a child's early education centre and children's subsequent educational attainment?}

Table 4 shows key coefficients from models examining relationships between proportion low-income peers in early education and FSP total score. The first four columns refer to the OLS specifications, while the fifth reports results from the fixed effects specification. Figure 6 shows model predicted probabilities for children who are themselves low-income, from OLS models 2, 3 and 4, and fixed effects (Model 5), respectively.

When the association between level of similarly low-income peers and FSP score is estimated without controlling for covariates (Model 1), low-income children in centres with over $50 \%$ low-income peers ( $3 \%$ of the sample) display the lowest score. Across the rest of the distribution, the relationship tends to be negative, but with a slight kink for children in centres with 40-50\% low-income peers, who tend to do as well as children in centres with $10-20 \%$ low-income peers. The negative relationship between having a majority similarly low-income peers and attainment 
echoes findings in the US literature, while the U-shape is congruent with patterns found in previous analyses of the data for older children in England.

However, Table 4 also shows that even in this model without controls, the magnitude of the relationships between proportion peers low-income and FSP score is small compared to differences by children's own family income-level.

When additional child-level factors are included (Model 2), results remain largely similar, while associations with levels of low-income peers become substantively negligible in Model 3 , as both main and interacted coefficients are reduced. Model 3 accounts for area factors and further analyses (not shown; available from authors on request) indicate neighbourhood poverty rate as the key factor accounting for the association in Models 1 and 2 between peer group and outcomes. Children living in areas of high poverty achieve lower FSP scores, even after controlling for individual characteristics. But our results suggest that these apparent area effects are not channelled, even partially, through peers in early education, but must operate through other mechanisms: children living in similarly poor areas but attending centres with different peer compositions achieve similar scores in their FSP.

The fourth model controls for other characteristics of children's early education centres - type of centre, qualification of staff, Ofsted judgement, size, whether open all year round, and also composition by ethnicity and home language. This does not change results. Only for children with no low-income peers is the association slightly stronger, suggesting sorting into different types of centre.

Overall then, results from the OLS model indicate an essentially null direct relationship from peer composition to FSP score. This pattern is confirmed by the 
fixed effect model, which compares children in the same primary school who attended early education centres with different levels of low-income peers. Again, there is little relationship between constitution by income-level of low-income children's early education settings and their FSP result.

Table 5 and Figure 7 show analyses replicated with FSP GLD as the outcome, rather than FSP total score. In Model 1, the raw association between a low-income child's likelihood of being attributed a GLD and her peer composition in early education is similar to that found using the continuous FSP total outcome: on average, those in centres with over $50 \%$ similarly low-income peers are less likely to be denoted as attaining a GLD. Again, however, differences according to peer constitution are small compared to difference according to children's own incomelevels.

By Model 5, which incorporates school fixed effects, the relationship between pre-school constitution and GLD score has largely flattened: the biggest difference estimated is between children in centres with $50 \%+$ low-income peers and those in centres with $40.1-50 \%$, but the effect is small (.07 of a standard deviation).

\section{Sensitivity checks}

We use a range of alternative specifications to check whether analytical decisions and constructs have influenced our results. Checks span different attainment outcomes, various sub-groups of pupils, delineation of setting types, and alternative model controls. They are detailed in the online supplementary materials, and continue consistently to suggest that the association between early education peer constitution by income-level and low-income children's formally recorded early school attainment appears to be substantively negligible. 


\section{Discussion}

This study attempts comprehensively to examine the extent of clustering by family income-level in early education centres in England, and associations with early reported school attainment. While there is growing interest in the potential of early education to narrow developmental gaps, peer composition has been relatively overlooked as a theoretically feasible instrumental factor.

Existing research has found evidence of peer effects for children with less developed language, or from families with lower socio-economic status. But these studies focus on a single town or area, or use surveys which provide data on only a handful of the children's peers, limiting wide-scale generalisability. Concentrating on low-income children, because they tend to be at a disadvantage throughout their education, our study uses a national census of all children born in one academic year in England to get a full picture both of the extent to which children with different family income levels attend differently constituted settings, and of the association between the full peer group and a child's early attainment, as recorded by teachers at the end of the first year of primary school.

We find some evidence of mild clustering by income-level: low-income children are more likely to attend centres with more similarly low-income peers than highincome children are. However, in very few centres are low-income children a majority: just $3 \%$ of children from low-income households attend provision where more than half of their peers are also low-income.

When comparing peer composition in pre-school to year 1 of compulsory schooling, patterns are very similar. The main difference is that there are some children who do not appear to mix with any low-income peers in early education 
$(24 \%)$ - and this is less common in primary school (13\%). Thus there is evidence of clustering among higher-income but not low-income children (as least so far as income is measured by our FSM proxy). Beyond this extreme of no low-income peers, patterns of sorting into early education largely resemble those for primary school. This might be the result of universal eligibility to free places, operating under the early years curriculum, and regulated by a national inspection system. Despite the complex mixed market of providers in England, these mechanisms may discourage highly disproportionate concentration of children from lower-income backgrounds.

We find associations between proportion of peers from low-income households and children's early attainment in unadjusted models, but the size of these associations (always small) becomes negligible once individual, centre and area characteristics are controlled for. In particular, accounting for level of child poverty in the family's residential area substantially reduces the association between peer make-up and outcomes. Similar children score less well if they come from areas with higher levels of poverty, but peer make-up in early education does not appear to be a mechanism for this. It seems unlikely that the apparent absence of peer effects results from sorting of children into centres, as we would expect any such bias to be upwards, inflating observed relationships with peer levels and creating 'false positives' in results. Findings from the school fixed effect specification, which may partly account for sorting on unobservables, also suggest the association is negligible.

Our indications of an essentially null relationship between peer constitution by income-level and subsequent attainment differ somewhat from patterns identified in preceding literature. This may be for a number of reasons. Firstly, the lack of 
association might result from the patterns of dispersion of low-income children across centres in England: in our analytical year of interest, at least, it seems that low-income children may not have been concentrated in proportions that would engender any relationships at scale. The lowered scores that we observe for the very few children in centres with over $50 \%$ fellow low-income peers speaks to this, and suggests that, nationally, children in England were distributed in this year rather optimally - at least so far as potential peer processes for those from low-income families may be concerned, and according to the weight of previous evidence.

On the other hand, our findings may to some extent be an artefact of the blunt, non-immediate measure with which we proxy income-level. Though FSM has been shown to provide a reasonably valid indication of family circumstance, it does not capture all very low-income families (Ilie et al, 2017). Further, our analytical year of interest is removed from initial observation of FSM take-up, and the binary nature of the variable masks nuanced variations at the individual and peer-group levels, which might relate to children's attainment. Moreover, as we are only able to measure peer-group at the setting level, we do not observe immediate interactions. Finally, the FSP attainment measure is an inexact representation of children's manifest capacities, and is in part a product of surrounding structural and institutional processes and pressures, rather than an immediately direct proxy for the child herself (Bradbury and Roberts-Holmes, 2017).

So it is feasible that there are associations for the children in our sample between peers and development that are not conveyed by the data available. Some of the previous studies which have found greater apparent effect have used measures formulated specifically to rate children's progress immediately after exposure to different peer-levels, and we, in contrast, use observational data for 
routinely collected, high-stakes FSP assessments, a year removed from the early education experience. Conversely, however, our use of these data, and corresponding null findings, may invite caution in interpretation of results conveyed by within-study measures tailored specifically to and used for research: their external validity in proxying impact in practice, and in the longer term, might be limited.

Our overall results indicating little association between peer mix by incomelevel and low-income children's attainment should be caveated according to the limitations of our measures and methods, but also contextualised in our findings on minimal clustering and sorting. Nationally, children in England, in 2011, were fairly evenly dispersed (according to our measure) across early education centres - and, perhaps accordingly, there is scant patterning of early attainment by peer constitution using this measure.

Social mix is arguably desirable for reasons beyond its relationships with recorded academic progress (Gorard and Siddiqui, 2018), so the situation we have described may be seen primarily as one of reasonable levels of mixing by incomelevel in early education, both from the perspective of observed educational progress, and from that, potentially, of greater societal benefits. Whether this apparent equilibrium will be maintained in the context of recent major changes to funding of the early years is a question that we will explore in future research, as the data becomes available.

\section{References}

Allen, R. and Vignoles, A. (2007). What should an index of school segregation measure? Oxford Review of Education, 33(5), 643-668. 
Biedinger, N., Becker, B., and Rohling, I. (2008). Early Ethnic Educational Inequality: The Influence of Duration of Preschool Attendance and Social Composition, European Sociological Review, 24(2), 243-256.

Blanden, J., Hansen, K., McNally, S. (2017). Quality in Early Years Settings and Children's School Achievement, CEP Discussion Paper No. 1468.

Bradbury, B., Corak, M., Waldfogel, J., and Washbrook, E. (2015). Too Many Children Left Behind: The U.S. Achievement Gap in Comparative Perspective, New York: Russell Sage Foundation.

Bradbury, A. and Roberts-Holmes, G. (2017). Creating an Ofsted story: the role of early years assessment data in schools' narratives of progress, British Journal of Sociology of Education, 38(7), 943-955.

Bradbury, A. (2014). Early childhood assessment: observation, teacher 'knowledge' and the production of attainment data in early years settings, Comparative Education, 50(3), 322-339

Burger, K (2010). How does early childhood care and education affect cognitive development? An international review of the effects of early interventions for children from different social backgrounds, Early Childhood Research Quarterly, 25, 140-165.

Burgess, S., McConnell, B., Propper, C., and Wilson, D. (2004). Sorting and Choice in English Secondary Schools, CMPO Working Paper Series No. 04/111.

Cebolla-Boado, H., and Garrido Medina, L. (2011). The Impact of Immigrant Concentration in Spanish Schools: School, Class, and Composition Effects, European Sociological Review, 27(5), 606-623.

Cooper, K. (2017) Poverty and Parenting in the UK. PhD Thesis, London School of Economics and Political Science. London: LSE Theses Online.

Cooper, K. and Stewart, K. (2017) Does money affect children's outcomes? A systematic review. York: Joseph Rowntree Foundation.

David, A. H. (2010). The 'collateral impact' of pupil behaviour and geographically concentrated socio-economic disadvantage, British Journal of Sociology of Education, 31(3), 261-276.

DeLay, D., Hanish, L. D., Martin, C. L., and Fabes, R. A. (2016). Peer Effects on Head Start Children's Preschool Competency, Developmental Psychology, 52(1), 58-70.

Department for Education (2014). EYFSP attainment by pupil characteristics: 2013 to 2014, London: Department for Education.

Department for Education (2015). GCSE and equivalent attainment by pupil characteristics, 2013 to 2014 (Revised), London: Department for Education.

Department for Education (2017) Early Years Foundation Stage Profile Results by pupil characteristics: 2017 SFR60/2017. London: Department for Education.

Dickerson, A. and Popli, G. (2012). Persistent poverty and children's cognitive development: Evidence from the UK Millennium Cohort Study, London: Centre for Longitudinal Studies. 
Dumas, C., and Lefranc, A (2010). Early schooling and later outcomes: Evidence from pre-school extension in France, THEMA Working Papers, Université de Cergy-Pontoise.

Duncan, Greg J., and Katherine Magnuson. 2013. Investing in Preschool Programs, Journal of Economic Perspectives, 27(2): 109-32.

Ebert, S., Lockl, K., Weinert, S., Anders, Y., Kluczniok, K., and Rossbach, H.-G. (2013). Internal and external influences on vocabulary development in preschool children, School Effectiveness and School Improvement, 24(2), 138154.

Equality and Human Rights Commission (2015). Is Britain Fairer? The state of equality and human rights 2015, UK: Her Majesty's Stationery Office.

Gambaro, L., Stewart, K., and Waldfogel, J. (2015). A question of quality: do children from disadvantaged backgrounds receive lower quality early childhood education and care? British Educational Research Journal, 41 (4), 553-574.

Gorard, S. and Siddiqui, N. (2018). Grammar schools in England: a new analysis of social segregation and academic outcomes, British Journal of Sociology of Education, online early access.

Gorard, S. (2009). Does the index of segregation matter? The composition of secondary schools in England since 1996, British Educational Research Journal, 35(4), 639-652.

Havnes, Tarjei, and Magne Mogstad. 2011. No Child Left Behind: Subsidized Child Care and Children's Long-Run Outcomes, American Economic Journal: Economic Policy, 3(2): 97-129.

Henry, G. T., and Rickman, D. K. (2007). Do peers influence children's skill development in preschool? Economics of Education Review, 26(1), 100-112.

Huskinson, T., Hobden, S., Oliver, D., Keyes, J., Littlewood, M., Pye, J., and Tipping, S. (2016). Childcare and early years survey of parents 2014 to 2015, London: Department for Education.

Ilie, S., Sutherland, A., and Vignoles, A. (2017). Revisiting free school meal eligability as a proxy for pupil socio-economic deprivation, British Educational Research Journal, 43(2), 253-274.

Iniesta-Martinez, S. and Evans, H. (2014). Pupils not claiming free school meals, London: Department for Education.

Jenkins, Stephen P. and Micklewright, John and Schnepf, Sylke (2008) Social segregation in secondary schools: how does England compare with other countries? Oxford Review of Education, 34 (1). pp. 21-37.

Johnston, R., Burgess, S., Harris, R. and Wilson, D. (2008). Sleepwalking to segregation? The changing ethnic composition of English schools, 1997-2003: an entry cohort analysis, Transactions of the Institute of British Geographers, 33(1), 73-90.

Justice, L. M., Petscher, Y., Schatschneider, C., and Mashburn, A. (2011). Peer Effects in Preschool Classrooms: Is Children's Language Growth Associated With Their Classmates' Skills? Child Dev, 82(6), 1768-1777. 
Kirby, P. and Cullinane, C. (2016). Class differences: Ethnicity and disadvantage, Research Brief: Edition 14. London: The Sutton Trust.

Lewis, J. and West, A. (2017). Early Childhood Education and Care in England under Austerity: Continuity or Change in Political Ideas, Policy Goals, Availability, Affordability and Quality in a Childcare Market? Journal of Social Policy, 46(2), 331-348.

Lloyd, E. and Penn, H. (2012). Childcare Markets: Can they deliver an equitable service? Bristol: Policy Press.

Mashburn, A. J., Justice, L. M., Downer, J. T., and Pianta, R. C. (2009). Peer Effects on Children's Language Achievement During Pre-Kindergarten, Child Dev, 80(3), 686-702.

Mathers, S., Singler, R., and Karemaker, A. (2012). Improving quality in the early years: A comparison of perspectives and measures, Nuffied Foundation: London.

Ofsted (2011). The Annual Report of Her Majesty's Chief Inspector of Education, Children's Services and Skills, London: The Stationery Office.

Moss, P., and Owen, C. (1989). Use of pre-school daycare and education 1979-86, Children and Society, 3(4), 296-310.

Ribeiro, L. A., Zachrisson, H. D., and Dearing, E. (2017). Peer effects on the development of language skills in Norwegian childcare centers, Early Childhood Research Quarterly, 41(C), 1-12.

Ruhm, C. and Waldfogel, J. (2012). Long-Term Effects of Early Childhood Care and Education, IZA DP No. 6149.

Sacerdote, B. (2011). Peer Effects in Education: How Might They Work, How Big Are They and How Much Do We Know Thus Far? In E. Hanusheck, S. Machin, and L. Woessmann (Eds.), Handbook of the Economics of Education (Vol. 3). Amsterdam: Elsevier.

Schechter, C., and Bye, B. (2007). Preliminary evidence for the impact of mixedincome preschools on low-income children's language growth, Early Childhood Research Quarterly, 22(1), 137-146.

Shaw, B., Baars, S., Menzies, L., LKMco, Parameshwaran, M. and Allen, R. Low income pupils' progress at secondary school, London: Social Mobility Commission.

Sutton Trust (2009). Attainment gaps between pupils in the most deprived and advantaged schools, London: Sutton Trust.

Stewart, K. (2013). Labour's Record on the Under Fives: Policy, Spending and Outcomes 1997-2010, London: CASE report 176.

Stewart, K. and Obolenskaya, P. (2015). The Coalition's Record on the Under Fives: Policy, Spending and Outcomes 2010-2015, London: CASE SPCC report 12.

Sylva, K., Melhuish, E., Sammons, P., Siraj-Blatchford, I.,Taggart, B. (2004). The Effective Provision of Pre-School Education (EPPE) Project: Final Report, Nottingham: DfES. 
Taylor, C. (2018). The Reliability of Free School Meal Eligibility as a Measure of Socio-Economic Disadvantage: Evidence from the Millennium Cohort Study in Wales, British Journal of Educational Studies, 66(1), 29-51.

Vincent, C., Braun, A., and Ball, S.J. (2008). Childcare, choice and social class: Caring for young children in the UK, Critical Social Policy, 28(1), 5-26.

Weiland, C., and Yoshikawa, H. (2014). Does higher peer socio-economic status predict children's language and executive function skills gains in prekindergarten? Journal of Applied Developmental Psychology, 35(5), 422432. 
Table 1: Structure of the data

\begin{tabular}{|c|c|c|c|c|}
\hline Year & January 2011 & 2012 & 2013 & 2014 \\
\hline School year & $\begin{array}{l}\text { Penultimate } \\
\text { academic year } \\
\text { before formal } \\
\text { school entry }\end{array}$ & $\begin{array}{l}\text { Reception class: } \\
\text { first year of } \\
\text { formal schooling }\end{array}$ & $\begin{array}{l}\text { Year 1: second } \\
\text { year of formal } \\
\text { schooling }\end{array}$ & $\begin{array}{l}\text { Year 2: third } \\
\text { year of formal } \\
\text { schooling }\end{array}$ \\
\hline Children's age & Age: $3-4$ & Age: $4-5$ & Age: $5-6$ & Age: 6-7 \\
\hline $\begin{array}{l}\text { Child level } \\
\text { variables: } \\
\text { Socio- } \\
\text { demographic } \\
\text { characteristics }\end{array}$ & $\begin{array}{l}\text { Gender } \\
\text { Ethnicity } \\
\text { Home language } \\
\text { Month of birth } \\
\text { Special Educational } \\
\text { Need } \\
\text { Local area identifier } \\
\text { (LSOA) } \\
\text { Hours per week of } \\
\text { ECEC attendance }\end{array}$ & $\begin{array}{l}\text { Ethnicity } \\
\text { Home language } \\
\text { Free school } \\
\text { meals }\end{array}$ & $\begin{array}{l}\text { Ethnicity } \\
\text { Home } \\
\text { language } \\
\text { Free school } \\
\text { meals }\end{array}$ & $\begin{array}{l}\text { Ethnicity } \\
\text { Home } \\
\text { language } \\
\text { Free school } \\
\text { meals }\end{array}$ \\
\hline $\begin{array}{l}\text { Child level } \\
\text { variables: outcome }\end{array}$ & & $\begin{array}{l}\text { Foundation Stage } \\
\text { Profile scores }\end{array}$ & & $\begin{array}{l}\text { Key Stage } \\
\text { One scores }\end{array}$ \\
\hline $\begin{array}{l}\text { Child's local area } \\
\text { variables*: }\end{array}$ & $\begin{array}{l}\text { Proportion of } \\
\text { children who are } \\
\text { low-income* } \\
\text { The government } \\
\text { office region }\end{array}$ & & & \\
\hline $\begin{array}{l}\text { ECEC } \\
\text { setting/school level } \\
\text { variables }\end{array}$ & $\begin{array}{l}\text { ECEC setting } \\
\text { identifier } \\
\text { Most recent Ofsted } \\
\text { inspection rating } \\
\text { Whether qualified } \\
\text { teachers and / or } \\
\text { early years } \\
\text { professionals work } \\
\text { with } 3-4 \text { year-olds } \\
\text { Number of weeks } \\
\text { per year open } \\
\text { Total number of } \\
\text { children in this age } \\
\text { group attending } \\
\text { Type of ECEC } \\
\text { setting (e.g. private } \\
\text { day care, school } \\
\text { nursery, voluntary } \\
\text { sector setting) }\end{array}$ & $\begin{array}{l}\text { Primary school } \\
\text { identifier } \\
\text { Most recent } \\
\text { Ofsted inspection } \\
\text { rating** }\end{array}$ & & \\
\hline
\end{tabular}

*This information is linked in from external data sources rather than being provided within the NPD, and is matched on each child's local area identifier (LSOA)

** Ofsted Inspection information is linked from external data source and is matched on the centre identifier. 


\section{Panel 1: Main variables}

\begin{tabular}{|c|c|c|c|}
\hline 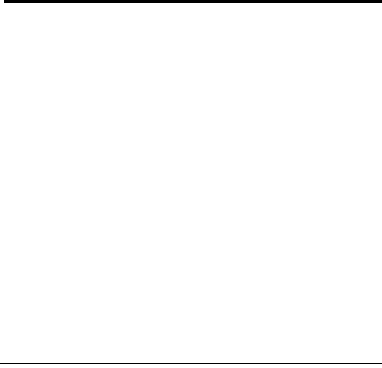 & $\begin{array}{l}\text { Child always FSM } \\
\text { Child sometimes FSM } \\
\text { Child never FSM } \\
\text { FSP total score } \\
\text { FSP GLD } \\
\text { FSP not GLD } \\
\text { Percent peers always FSM } \\
\text { Percent peers sometimes FSM } \\
\text { Percent peers never FSM }\end{array}$ & $\begin{array}{l}12.4 \\
12.1 \\
75.5 \\
89.2(15.8) \\
64.7 \\
35.3 \\
11.9(12.04) \\
11.9(9.31) \\
72.8(18.31) \\
\end{array}$ & $\begin{array}{r}68.638 \\
67,178 \\
417,511\end{array}$ \\
\hline \multicolumn{4}{|c|}{ Panel 2: Child characteristics } \\
\hline \multirow[t]{30}{*}{ Month and year of birth } & September 2006 & 8.71 & 48,196 \\
\hline & October 2006 & 8.62 & 47,702 \\
\hline & November 2006 & 8.2 & 45,388 \\
\hline & December 2006 & 8.09 & 44,751 \\
\hline & January $\quad 2007$ & 8.26 & 45,707 \\
\hline & February 2007 & 7.58 & 41,954 \\
\hline & March & 8.24 & 45,582 \\
\hline & April & 7.9 & 43,709 \\
\hline & May & 8.58 & 47,488 \\
\hline & June & 8.22 & 45,476 \\
\hline & July & 8.82 & 48,818 \\
\hline & August & 8.78 & 48,556 \\
\hline & 0 Missing always & 0.32 & 1,759 \\
\hline & 1 Bangladeshi & 1.6 & 8,871 \\
\hline & 2 Indian & 2.68 & 14,821 \\
\hline & 3 Any other Asian & 1.79 & 9,887 \\
\hline & 4 Pakistani & 4.27 & 23,610 \\
\hline & 5 Black African & 3.54 & 19,589 \\
\hline & 6 Black Caribbean & 1.14 & 6,318 \\
\hline & 7 Any other Black & 0.72 & 3,964 \\
\hline & 8 Chinese & 0.38 & 2,097 \\
\hline & 9 Any other mixed & 1.82 & 10,066 \\
\hline & 10 White and Asian & 1.2 & 6,650 \\
\hline & 11 White and Black African & 0.71 & 3,943 \\
\hline & 12 White and Black Caribbean & 1.45 & 8,007 \\
\hline & 15 Any other ethnic group & 1.58 & 8,735 \\
\hline & 17 White British & 72.13 & 399,108 \\
\hline & 18 White Irish & 0.24 & 1,312 \\
\hline & Gypsy / Roma / Irish Traveller & 0.18 & 1,017 \\
\hline & 20 Any other White & 4.26 & 23,573 \\
\hline \multirow{3}{*}{$\begin{array}{r}\text { English as additional } \\
\text { language (EAL) }\end{array}$} & No & 82.2 & 454,845 \\
\hline & Yes (at least once) & 17.7 & 97,923 \\
\hline & Always missing & 0.1 & 559 \\
\hline \multirow{2}{*}{$\begin{array}{r}\text { Recorded as having } \\
\text { Special Education } \\
\text { Need }\end{array}$} & No & 95.29 & 527,283 \\
\hline & Yes & 4.71 & 26,044 \\
\hline \multirow[t]{2}{*}{ Hours attended } & 15 hours or under & 76.29 & 422,155 \\
\hline & More than 15 hours & 23.71 & 131,172 \\
\hline
\end{tabular}


Panel 3: area characteristics

\begin{tabular}{|c|c|c|c|}
\hline Child poverty in the & $\frac{10}{102}+m$ & 010 & 50700 \\
\hline area where child lives. & 5 & 9.16 & 50.676 \\
\hline deciles & 3 & 9.61 & 53,192 \\
\hline & 4 & 9.68 & 53,549 \\
\hline & 5 & 9.8 & 54,222 \\
\hline & 6 & 10.15 & 56,188 \\
\hline & 7 & 10.28 & 56,876 \\
\hline & 8 & 10.36 & 57,324 \\
\hline & 9 & 10.59 & 58,587 \\
\hline & Poorest & 10.82 & 59,845 \\
\hline & Missing information & 0.39 & 2,162 \\
\hline Regions & East Midlands & 8.42 & 46,568 \\
\hline & East of England & 10.96 & 60,627 \\
\hline & N East & 4.93 & 27,263 \\
\hline & N West & 13.69 & 75,732 \\
\hline & South East & 15.85 & 87,725 \\
\hline & South West & 8.78 & 48,560 \\
\hline & West Mids & 11.14 & 61,664 \\
\hline & Yorks and Humber & 10.31 & 57,044 \\
\hline & Missing & 0.39 & 2,162 \\
\hline & Inner London & 5.44 & 30,088 \\
\hline & Outer London & 10.10 & 55,894 \\
\hline Early education in $L A$ & $0-24.9 \%$ & 26.25 & 145,257 \\
\hline provided in maintained & $25-49.9 \%$ & 23.58 & 130,462 \\
\hline settings & $50-74.9 \%$ & 34.29 & 189,761 \\
\hline & $75-100 \%$ & 15.88 & 87,847 \\
\hline Panel 4: preschool cha & acteristics & & \\
\hline Type of setting & School nursery & 49.49 & 273,860 \\
\hline & Indy school & 0.84 & 4,645 \\
\hline & LA day nursery & 1.02 & 5,636 \\
\hline & Other, not priv/vol sector & 1.53 & 8,458 \\
\hline & Priv/vol day nursery & 22.54 & 124,717 \\
\hline & Sure Start or Integrated Centre & 1.15 & 6,343 \\
\hline & Priv/vol nursery school & 1.22 & 6,773 \\
\hline & Priv/vol other & 0.38 & 2,077 \\
\hline & Priv/vol playgroup/preschool & 21.83 & 120,818 \\
\hline & School nursery & 49.49 & 273,860 \\
\hline & Indy school & 0.84 & 4,645 \\
\hline & LA day nursery & 1.02 & 5,636 \\
\hline Setting size & $1-20$ & 22.27 & 123,206 \\
\hline & $21-30$ & 23.52 & 130,154 \\
\hline & $31-50$ & 30.76 & 170,229 \\
\hline & $51-193$ & 23.45 & 129,738 \\
\hline Ofsted judgment & Outstanding & 12.61 & 69,758 \\
\hline & Good & 45.6 & 252,310 \\
\hline & Satisfactory & 13.23 & 73,196 \\
\hline & Inadequate & 0.49 & 2,711 \\
\hline & No information & 28.08 & 155,352 \\
\hline & Outstanding & 12.61 & 69,758 \\
\hline Opening weeks & 38 weeks or fewer & 70.6 & 390,662 \\
\hline & $38.5-50$ & 12.45 & 68,914 \\
\hline & $50.2-52$ & 16.94 & 93,751 \\
\hline
\end{tabular}




\begin{tabular}{rlrr} 
Staff qualifications & No QTS or EYP & 33.55 & 185,657 \\
& least 1 QTS or EYP & 16.95 & 93,810 \\
School setting & 49.49 & 273,860 \\
Other peers' & have EAL & $17.6(24.5)$ & \\
characteristics: \% & Bangladeshi & $1.6(6.9)$ & \\
peers who... & Indian & $2.8(7.5)$ & \\
& Any other Asian & $1.8(4.6)$ \\
& Pakistani & $4.2(12.6)$ \\
Black African & $3.5(8.4)$ \\
Black Caribbean & $1.1(4.0)$ \\
Any other Black & $0.7(2.6)$ \\
Chinese & $0.4(1.4)$ \\
Any other mixed & $1.8(3.4)$ \\
White and Asian & $1.2(2.5)$ \\
White and Black African & $0.7(1.9)$ \\
White and Black Caribbean & $1.4(3.0)$ \\
Any other ethnic group & $1.7(4.4)$ \\
White British & $70.8(30.5)$ \\
White Irish & $0.25(1.2)$ \\
Gypsy / Roma / Irish Traveller & $0.2(1.3)$ \\
Any other White & $4.4(7.6)$ \\
Missing always & $1.4(4.5)$ \\
\hline
\end{tabular}


Table 3: correlations between scales of the FSP

\begin{tabular}{|c|c|c|c|c|c|c|c|}
\hline & $\begin{array}{l}\bar{\pi} \\
0 \\
0 \\
0 \\
\mathbb{4}\end{array}$ & 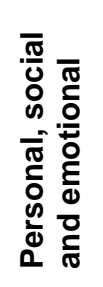 & 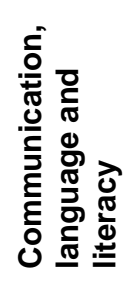 & 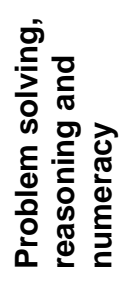 & 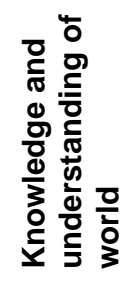 & 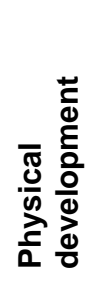 & 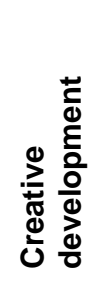 \\
\hline FSP total & 1.0 & & & & & & \\
\hline $\begin{array}{l}\text { Personal, social and } \\
\text { emotional }\end{array}$ & .9 & 1.0 & & & & & \\
\hline $\begin{array}{l}\text { Communication, } \\
\text { language and literacy }\end{array}$ & .96 & .79 & 1.0 & & & & \\
\hline $\begin{array}{l}\text { Problem solving, } \\
\text { reasoning and numeracy }\end{array}$ & .92 & .74 & .87 & 1.0 & & & \\
\hline $\begin{array}{l}\text { Knowledge and } \\
\text { understanding of world }\end{array}$ & .84 & .74 & .75 & .75 & 1.0 & & \\
\hline Physical development & .8 & .72 & .71 & .68 & .69 & 1.0 & \\
\hline Creative development & .79 & .71 & .7 & .66 & .71 & .67 & 1.0 \\
\hline
\end{tabular}


Table 4: Key coefficients from cumulative OLS models and FE model estimating relationships between proportion peers low-income and

Foundation Stage Profile total score

\begin{tabular}{|c|c|c|c|c|c|c|c|c|c|c|}
\hline \multirow[b]{2}{*}{ Never FSM } & \multicolumn{2}{|c|}{$\begin{array}{l}\text { Model 1: } \\
\text { No controls }\end{array}$} & \multicolumn{2}{|c|}{$\begin{array}{c}\text { Model 2: } \\
\text { Child characteristics }\end{array}$} & \multicolumn{2}{|c|}{$\begin{array}{l}\text { Model 3: Local area } \\
\text { characteristics }\end{array}$} & \multicolumn{2}{|c|}{$\begin{array}{c}\text { Model 4: Centre } \\
\text { characteristics }\end{array}$} & \multicolumn{2}{|c|}{$\begin{array}{l}\text { Model 5: } 4+ \\
\text { School FE }\end{array}$} \\
\hline & 0 & (.) & 0 & (.) & 0 & (.) & 0 & (.) & 0 & (.) \\
\hline Once or twice FSM & $-7.57^{\star \star \star}$ & $(0.18)$ & $-7.08^{* \star *}$ & $(0.16)$ & $-6.11^{* \star \star}$ & $(0.16)$ & $-5.96^{\star \star \star}$ & $(0.16)$ & $-5.19^{\star \star \star}$ & $(0.15)$ \\
\hline Always FSM & $-10.2^{* * \star}$ & $(0.23)$ & $-9.26^{* * *}$ & $(0.21)$ & $-8.00^{* * *}$ & $(0.21)$ & $-7.78^{\star \star \star}$ & $(0.21)$ & $-7.32^{* * *}$ & $(0.19)$ \\
\hline $0 \%$ always FSM peers & 0 & (.) & 0 & (.) & 0 & (.) & 0 & (.) & 0 & (.) \\
\hline $0.1-10 \%$ always FSM peers & $-1.68^{* \star \star}$ & $(0.06)$ & $-1.02^{* \star *}$ & $(0.06)$ & $-0.46^{* \star *}$ & $(0.06)$ & $-0.89^{* \star *}$ & $(0.06)$ & $-0.49^{\star * \star}$ & $(0.06)$ \\
\hline $10.1-20 \%$ always FSM peers & $-4.86^{\star \star \star}$ & $(0.07)$ & $-3.37^{\star \star \star}$ & $(0.06)$ & $-1.92^{\star \star \star}$ & $(0.07)$ & $-2.29^{\star \star \star}$ & $(0.07)$ & $-1.29^{* \star *}$ & $(0.08)$ \\
\hline $20.1-30 \%$ always FSM peers & $-6.96^{* \star \star}$ & $(0.09)$ & $-5.07^{\star \star \star}$ & $(0.08)$ & $-3.01^{\star \star \star}$ & $(0.09)$ & $-3.39^{\star \star \star}$ & $(0.09)$ & $-1.88^{\star \star \star}$ & $(0.10)$ \\
\hline $30.1-40 \%$ always FSM peers & $-7.22^{\star \star \star}$ & $(0.13)$ & $-5.49^{* \star \star}$ & $(0.12)$ & $-3.09^{\star \star *}$ & $(0.12)$ & $-3.47^{\star \star \star}$ & $(0.13)$ & $-1.99^{* \star *}$ & $(0.14)$ \\
\hline $40.1-50 \%$ always $\mathrm{FSM}$ peers & $-8.49^{* \star \star}$ & $(0.21)$ & $-6.58^{* \star *}$ & $(0.20)$ & $-3.89^{* \star \star}$ & $(0.20)$ & $-4.17^{\star \star \star}$ & $(0.20)$ & $-1.78^{\star \star \star}$ & $(0.21)$ \\
\hline $50.1 \%$ + always FSM peers & $-8.20^{\star \star \star}$ & $(0.41)$ & $-6.75^{\star \star \star}$ & $(0.38)$ & $-3.98^{\star \star \star}$ & $(0.38)$ & $-4.11^{\star \star \star}$ & $(0.38)$ & $-2.06^{\star \star \star}$ & $(0.38)$ \\
\hline Always FSM \# $0 \%$ always FSM peers & 0 & (.) & 0 & (.) & 0 & (.) & 0 & (.) & 0 & (.) \\
\hline Always FSM \# 0.1-10\% always FSM peers & $0.68^{*}$ & $(0.27)$ & $0.53^{*}$ & $(0.25)$ & 0.39 & $(0.25)$ & 0.21 & $(0.25)$ & 0.26 & $(0.22)$ \\
\hline Always FSM \# 10.1-20\% always FSM peers & $2.45^{\star \star \star}$ & $(0.26)$ & $2.07^{\star \star \star}$ & $(0.24)$ & $1.52^{\star \star \star}$ & $(0.24)$ & $1.27^{\star \star \star}$ & $(0.24)$ & $1.13^{\star \star \star}$ & $(0.22)$ \\
\hline Always FSM \# 20.1-30\% always FSM peers & $3.99^{\star \star \star}$ & $(0.27)$ & $3.25^{\star \star \star}$ & $(0.25)$ & $2.45^{\star \star \star}$ & $(0.25)$ & $2.20^{\star \star \star}$ & $(0.25)$ & $1.91^{\star \star \star}$ & $(0.23)$ \\
\hline Always FSM \# 30.1-40\% always FSM peers & $4.39^{\star \star \star}$ & $(0.30)$ & $3.67^{\star \star \star}$ & $(0.28)$ & $2.79^{\star \star \star}$ & $(0.27)$ & $2.53^{\star \star \star}$ & $(0.27)$ & $2.48^{\star \star \star}$ & $(0.25)$ \\
\hline Always FSM \# 40.1-50\% always FSM peers & $6.20^{\star \star \star}$ & $(0.38)$ & $5.22^{\star \star \star}$ & $(0.35)$ & $4.23^{\star \star \star}$ & $(0.35)$ & $3.94^{\star \star \star}$ & $(0.35)$ & $2.78^{\star \star \star}$ & $(0.32)$ \\
\hline Always FSM \# 50.1\% + always FSM peers & $3.59^{* \star *}$ & $(0.58)$ & $3.22^{\star \star \star}$ & $(0.53)$ & $2.39^{* \star *}$ & $(0.53)$ & $2.14^{\star \star *}$ & $(0.53)$ & $1.95^{\star * \star}$ & $(0.49)$ \\
\hline Constant & $94.0^{\star \star *}$ & $(0.04)$ & $97.2^{* * *}$ & $(0.08)$ & $101.5^{* * *}$ & $(0.14)$ & $100.3^{* \star *}$ & $(0.46)$ & $98.1^{* \star *}$ & $(0.55)$ \\
\hline Observations & 553327 & & 553327 & & 553327 & & 553327 & & 553327 & \\
\hline
\end{tabular}

Standard errors in parentheses ${ }^{+} p<.10,{ }^{*} p<.05,{ }^{* *} p<.01,{ }^{* * *} p<.001$. Outcome is FSP total score (range 0-117, mean = 89.2, SD: 15.8). Data source: National Pupil Database. Model 2 adds child gender, ethnicity, SEN in 2011, home language, month of birth, hours attending early education. Model 3 adds GOR, IDACI, proportion provision in LA in maintained sector. Model 4 adds early education center's staff qualifications, weeks open per year, Ofsted judgement, center size, center type, proportion peers EAL, proportion each ethnicity. Model 5 adds fixed effects for school at which FSP assessed in 2013. 
Table 5: Key coefficients from cumulative OLS models and FE model estimating relationships between proportion peers low-income and probability of being assessed as having a 'Good Level of Development' in the Foundation Stage Profile

\begin{tabular}{|c|c|c|c|c|c|c|c|c|c|c|}
\hline \multirow[b]{2}{*}{ Never FSM } & \multicolumn{2}{|c|}{$\begin{array}{l}\text { Model 1: } \\
\text { No controls }\end{array}$} & \multicolumn{2}{|c|}{$\begin{array}{l}\text { Model 2: } \\
\text { Child characteristics }\end{array}$} & \multicolumn{2}{|c|}{$\begin{array}{l}\text { Model 3: Local area } \\
\text { characteristics }\end{array}$} & \multicolumn{2}{|c|}{$\begin{array}{l}\text { Model 4: Centre } \\
\text { characteristics }\end{array}$} & \multicolumn{2}{|c|}{$\begin{array}{l}\text { Model 5: } 4+ \\
\text { School FE }\end{array}$} \\
\hline & 0 & $()$. & 0 & (.) & 0 & (.) & 0 & (.) & 0 & $()$. \\
\hline Once or twice FSM & $-0.19^{\star \star \star}$ & $(0.01)$ & $-0.18^{* \star \star}$ & $(0.01)$ & $-0.16^{\star \star \star}$ & $(0.01)$ & $-0.16^{\star \star \star}$ & $(0.01)$ & $-0.15^{\star \star *}$ & $(0.01)$ \\
\hline Always FSM & $-0.24^{* * *}$ & $(0.01)$ & $-0.22^{* * *}$ & $(0.01)$ & $-0.20^{* * *}$ & $(0.01)$ & $-0.20^{\star * \star}$ & $(0.01)$ & $-0.20^{\star * *}$ & $(0.01)$ \\
\hline $0 \%$ always $\mathrm{FSM}$ peers & 0 & (.) & 0 & (.) & 0 & $()$. & 0 & $()$. & 0 & (.) \\
\hline $0.1-10 \%$ always FSM peers & $-0.028^{* \star *}$ & $(0.00)$ & $-0.017^{\star \star \star}$ & $(0.00)$ & $-0.0078^{\star * *}$ & $(0.00)$ & $-0.015^{\star * \star}$ & $(0.00)$ & $-0.015^{* \star *}$ & $(0.00)$ \\
\hline $10.1-20 \%$ always FSM peers & $-0.082^{* \star \star}$ & $(0.00)$ & $-0.057^{* * *}$ & $(0.00)$ & $-0.033^{\star \star \star}$ & $(0.00)$ & $-0.041^{* * *}$ & $(0.00)$ & $-0.036^{\star * \star}$ & $(0.00)$ \\
\hline $20.1-30 \%$ always FSM peers & $-0.11^{* * *}$ & $(0.00)$ & $-0.084^{\star \star \star}$ & $(0.00)$ & $-0.051^{* \star *}$ & $(0.00)$ & $-0.060^{\star * \star}$ & $(0.00)$ & $-0.052^{* \star *}$ & $(0.00)$ \\
\hline $30.1-40 \%$ always FSM peers & $-0.11^{* * *}$ & $(0.00)$ & $-0.087^{\star \star \star}$ & $(0.00)$ & $-0.051^{\star \star \star}$ & $(0.00)$ & $-0.060^{\star * \star}$ & $(0.00)$ & $-0.059^{* \star *}$ & $(0.00)$ \\
\hline $40.1-50 \%$ always FSM peers & $-0.12^{\star \star \star}$ & $(0.01)$ & $-0.090^{* \star *}$ & $(0.01)$ & $-0.050^{* \star *}$ & $(0.01)$ & $-0.058^{* \star *}$ & $(0.01)$ & $-0.056^{* * *}$ & $(0.01)$ \\
\hline $50.1 \%$ + always FSM peers & $-0.14^{* \star *}$ & $(0.01)$ & $-0.12^{* \star \star}$ & $(0.01)$ & $-0.079^{* * *}$ & $(0.01)$ & $-0.084^{* \star *}$ & $(0.01)$ & $-0.072^{* * *}$ & $(0.01)$ \\
\hline Always FSM \# $0 \%$ always FSM peers & 0 & $()$. & 0 & $()$. & 0 & $()$. & 0 & $()$. & 0 & $()$. \\
\hline Always FSM \# $0.1-10 \%$ always FSM peers & -0.00033 & $(0.01)$ & -0.0039 & $(0.01)$ & -0.0069 & $(0.01)$ & -0.010 & $(0.01)$ & -0.0086 & $(0.01)$ \\
\hline Always FSM \# 10.1-20\% always FSM peers & $0.041^{* * *}$ & $(0.01)$ & $0.033^{\star \star \star}$ & $(0.01)$ & $0.021^{\star \star}$ & $(0.01)$ & $0.017^{\star}$ & $(0.01)$ & $0.019^{*}$ & $(0.01)$ \\
\hline Always FSM \# 20.1-30\% always FSM peers & $0.077^{* * *}$ & $(0.01)$ & $0.062^{* * *}$ & $(0.01)$ & $0.046^{* * *}$ & $(0.01)$ & $0.042^{* * *}$ & $(0.01)$ & $0.038^{* * *}$ & $(0.01)$ \\
\hline Always FSM \# 30.1-40\% always FSM peers & $0.086^{* * *}$ & $(0.01)$ & $0.072^{\star * *}$ & $(0.01)$ & $0.054^{* * *}$ & $(0.01)$ & $0.049^{* * *}$ & $(0.01)$ & $0.049^{* * *}$ & $(0.01)$ \\
\hline Always FSM \# 40.1-50\% always FSM peers & $0.12^{* \star *}$ & $(0.01)$ & $0.10^{\star \star \star}$ & $(0.01)$ & $0.083^{* * *}$ & $(0.01)$ & $0.078^{\star \star \star}$ & $(0.01)$ & $0.068^{* \star *}$ & $(0.01)$ \\
\hline Always FSM \# 50.1\% + always FSM peers & $0.082^{* \star *}$ & $(0.02)$ & $0.075^{\star \star \star}$ & $(0.02)$ & $0.059^{* * *}$ & $(0.02)$ & $0.054^{* *}$ & $(0.02)$ & $0.057^{\star \star \star}$ & $(0.02)$ \\
\hline Constant & $0.74^{* \star *}$ & $(0.00)$ & $0.78^{\star \star *}$ & $(0.00)$ & $0.88^{* * *}$ & $(0.00)$ & $0.89^{* * *}$ & $(0.01)$ & $0.84^{* * *}$ & $(0.02)$ \\
\hline Observations & 553327 & & 553327 & & 553327 & & 553327 & & 553327 & \\
\hline
\end{tabular}

Standard errors in parentheses ${ }^{+} p<.10,{ }^{*} p<.05,{ }^{* *} p<.01,{ }^{* * *} p<.001$. Data source: National Pupil Database. Model 2 adds child gender, ethnicity, SEN in 2011, home language, month of birth, hours attending early education. Model 3 adds GOR, IDACI, proportion provision in LA in maintained sector. Model 4 adds early education center's staff qualifications, weeks open per year, Ofsted judgement, center size, center type, proportion peers EAL, proportion each ethnicity. Model 5 adds fixed effects for school at which FSP assessed in 2013. 
Figure 1: Proportion of peers who are low income

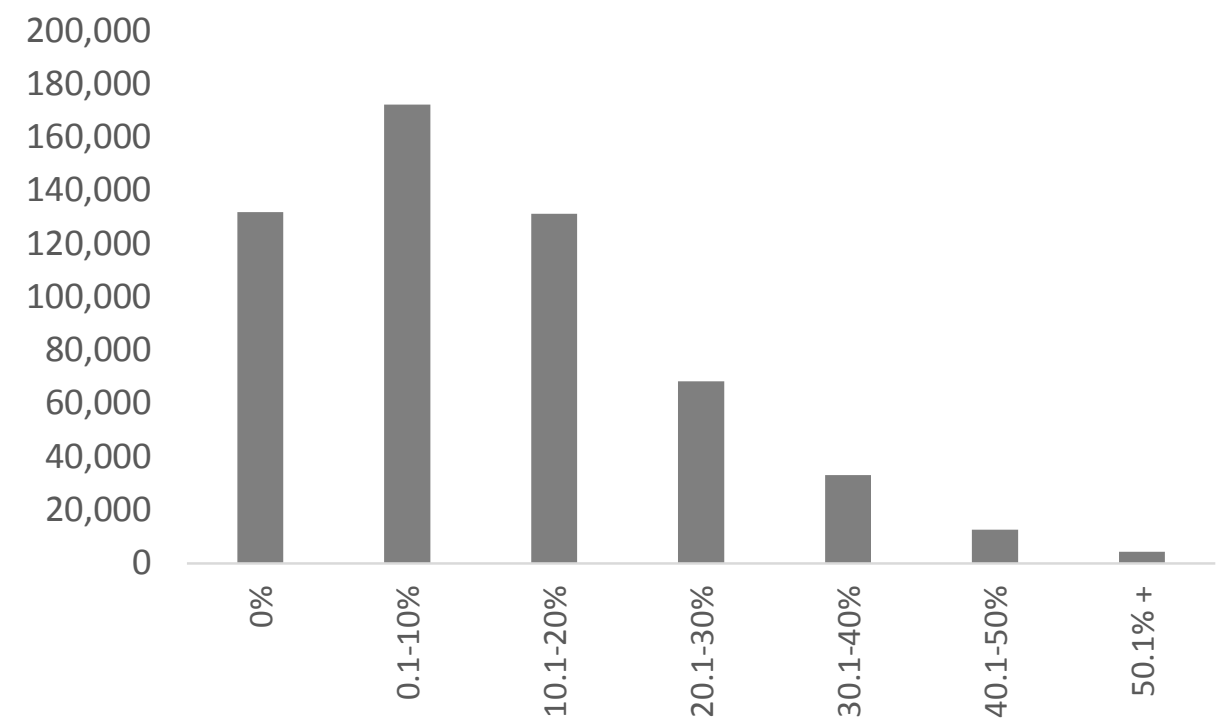

Note: Low income = 'always FSM.' $N=553,327$. Source: National Pupil Database. 
Figure 2: Distribution of sample children across early education centres with each level of low-income peers, by child's own income level

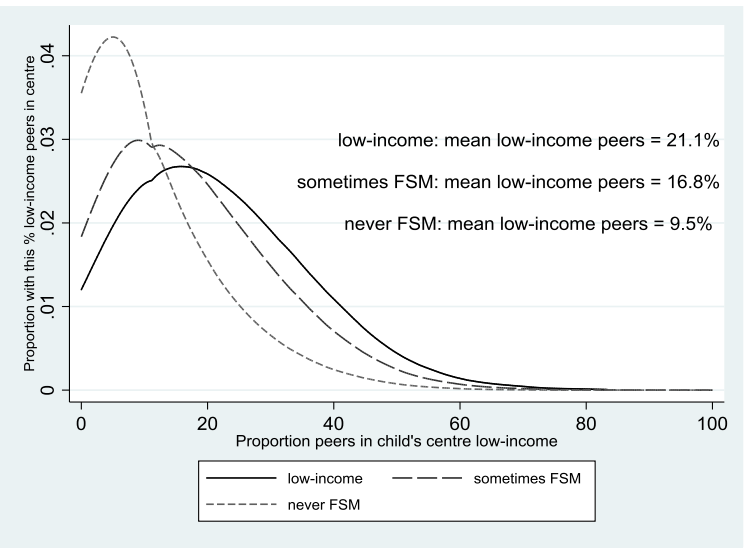

Note: Low income = 'always FSM.' N = 553,327. Source: National Pupil Database. 
Figure 3: Distribution of sample children across early education centre with each level of low-income peers, by child's own income level, split by centre type

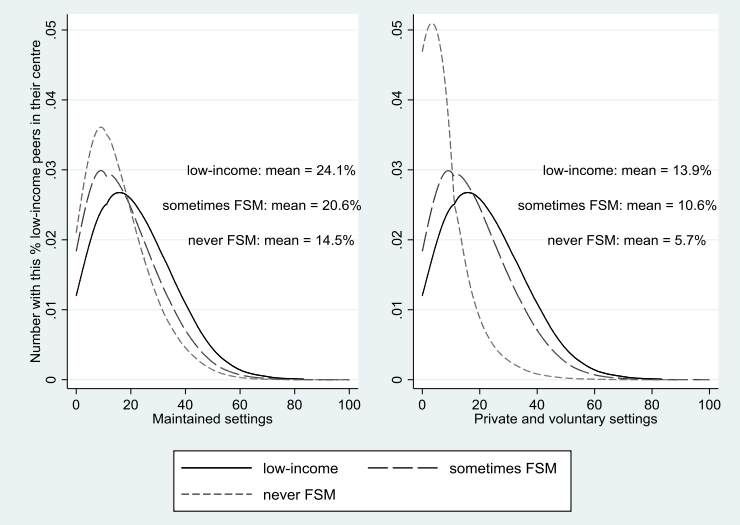

Note: Low income = 'always FSM.' $N=553,327$. Source: National Pupil Database. 
Figure 4: Number of sample children with each level of peers low-income, across early education centres in 2011 and primary schools at year 1, in 2013 250,000

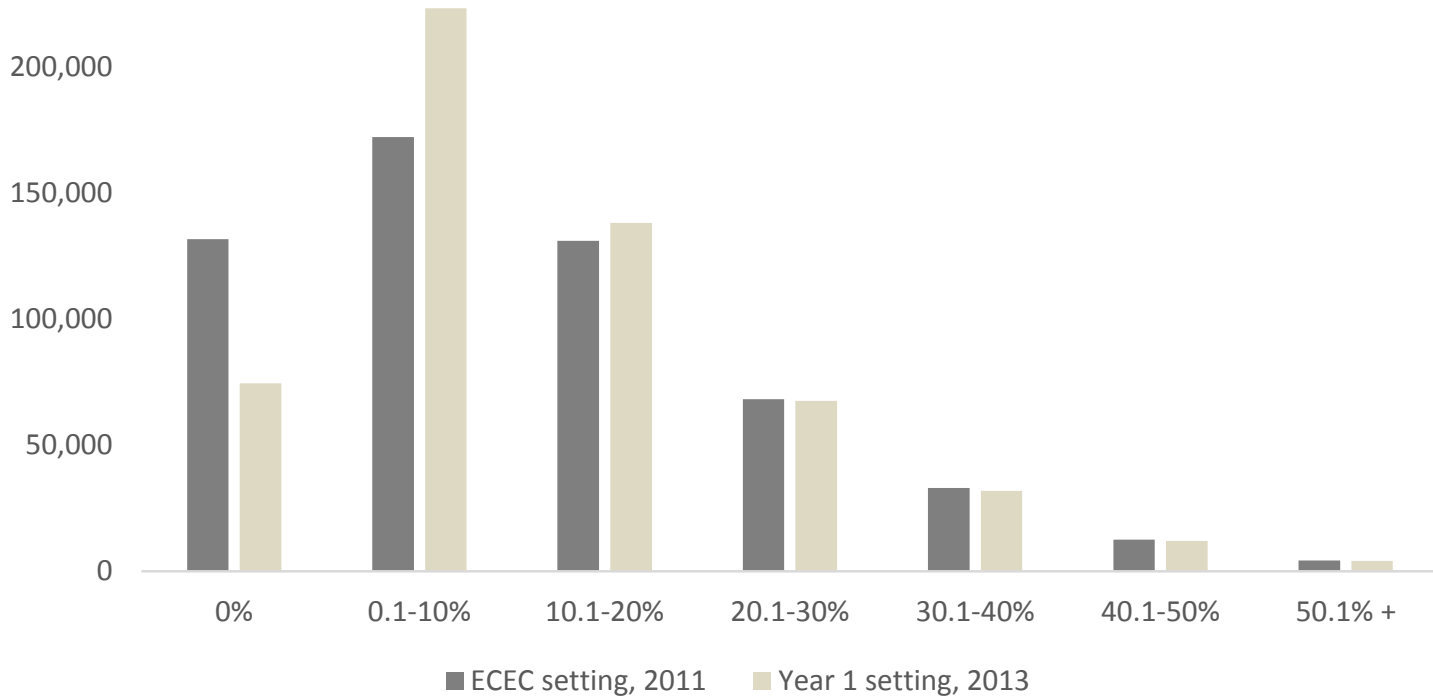

Note: Low income = 'always FSM.' N=551,713. Source: National Pupil Database. 
Figure 5: Distribution of sample children across early education centres and primary schools at year 1 , with each level of low-income peers, by child's own income level

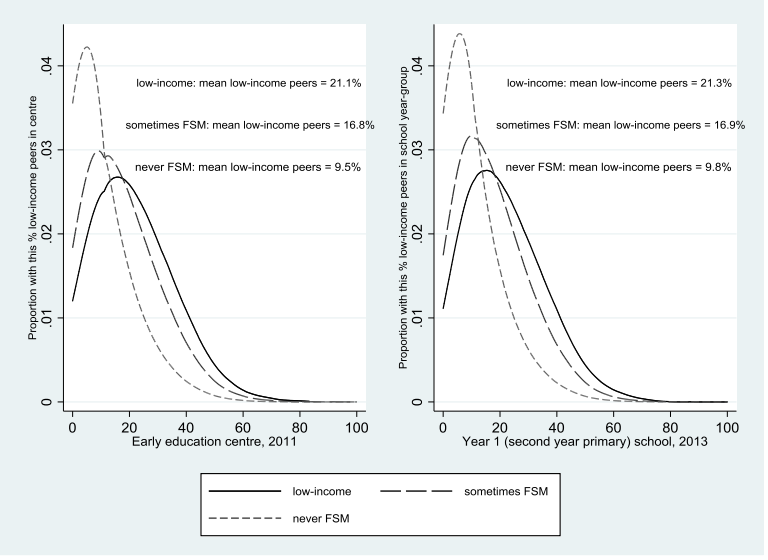

Note: Low income = 'always FSM.' N=551,713. Source: National Pupil Database. 
Figure 6: Model estimated mean Foundation Stage Profile total scores, for children themselves low-income, according to proportion low-income peers in their early education centre
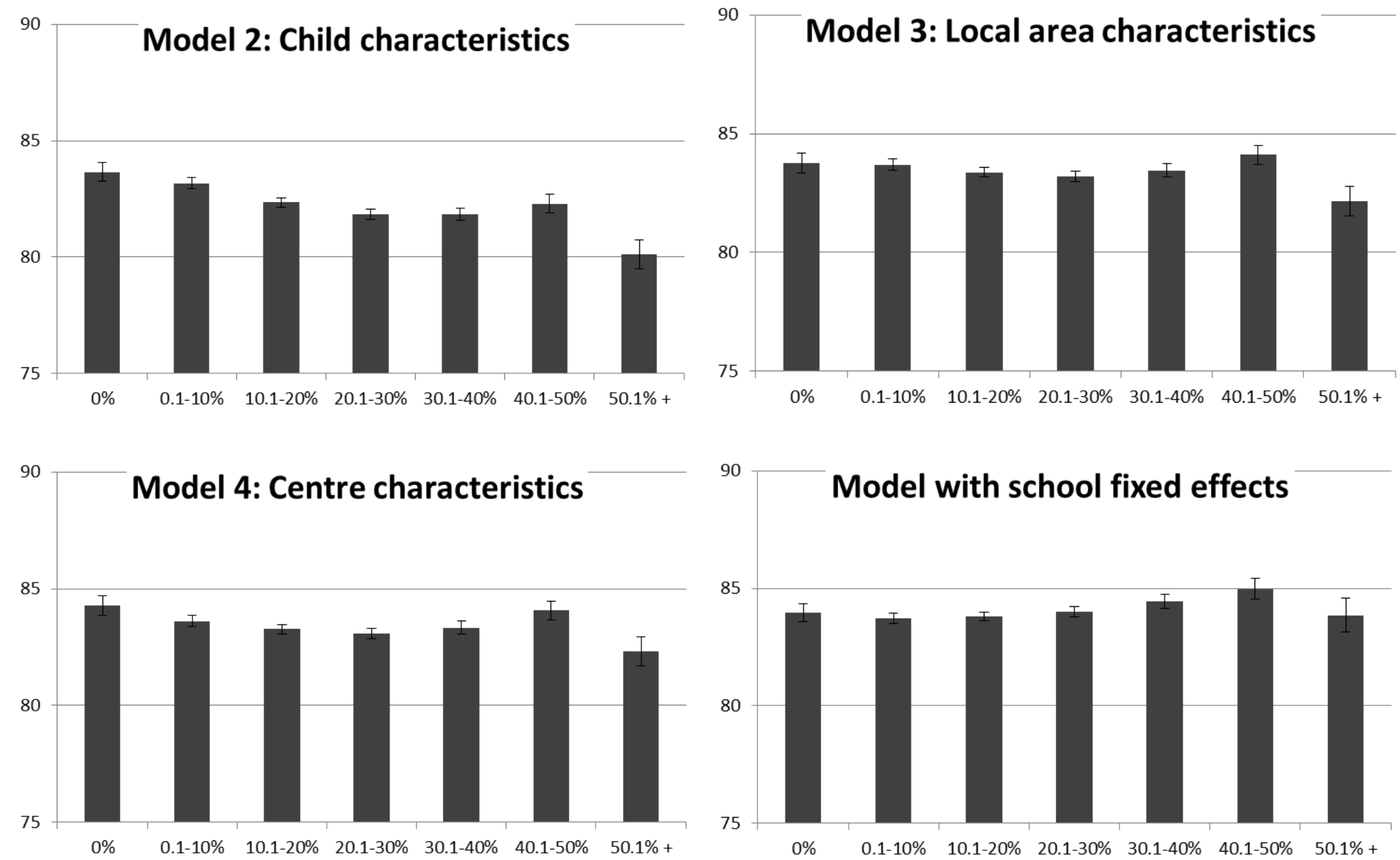

All Models: $\mathrm{N}=553,327$. See Tables 2, 4 for details of covariates. Outcome is FSP total score (range 0-117, mean $=89.2$, SD: 15.8$)$. Error bars $=95 \% \mathrm{Cl}$. 
Figure 7: Model estimated probability of being assessed as attaining a Good Level of Development (GLD), for children themselves low-income, according to proportion low-income peers in their early education centre
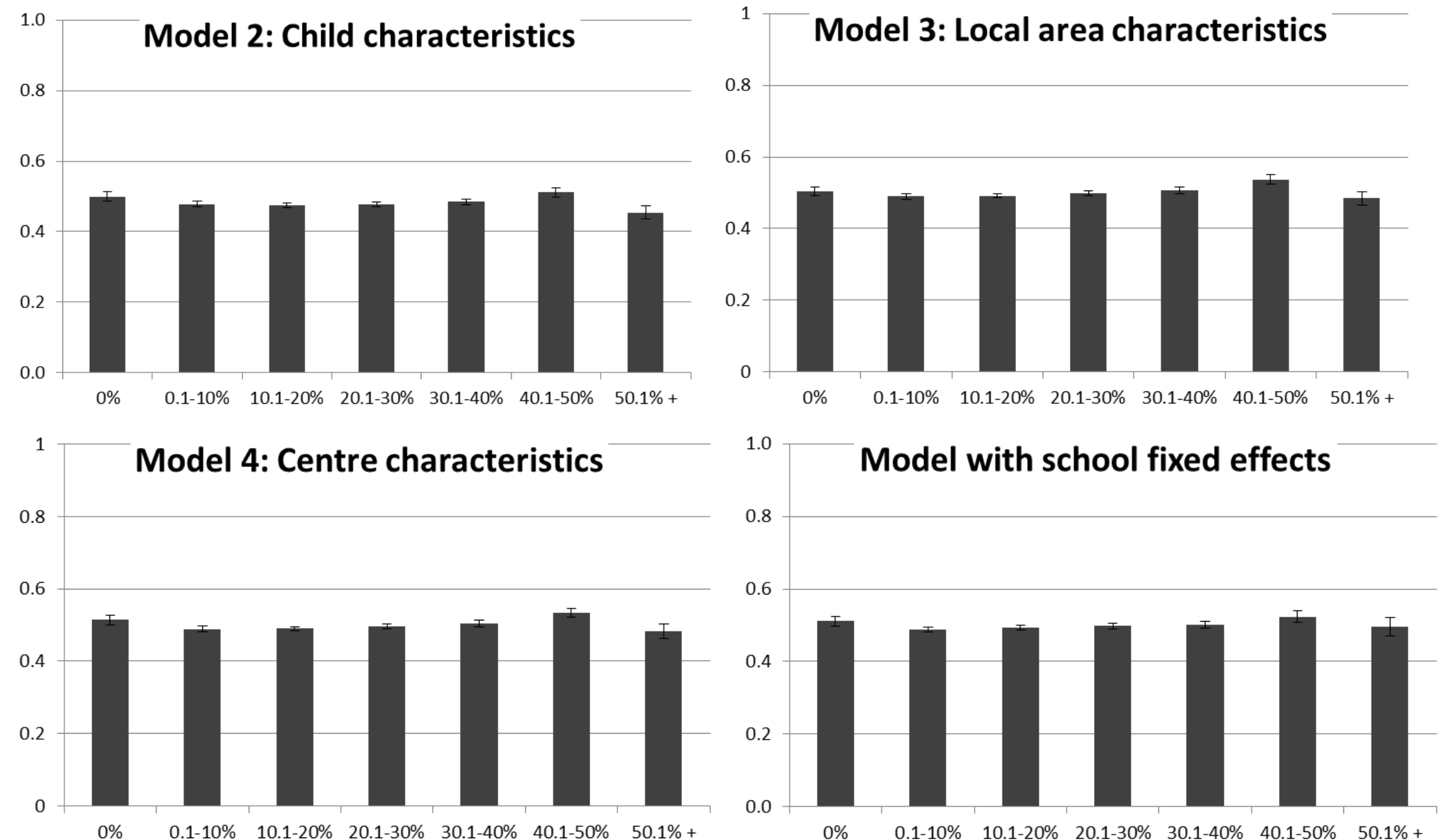

All Models: $\mathrm{N}=553,327$. See Tables 2, 5 for details of covariates. Error bars $=95 \% \mathrm{Cl}$ 